\title{
アイソトープキャリブレータの測定精度 （被測定液量と容器に対する補正）
}

\author{
広島大学医学部附属病院放射線部 \\ 谷口金吾·宮川忠重・土井信一格 \\ 広島大学原爆放射能医学研究所 \\ 砂 屋 敷 忠 \\ （論文受理＼cjkstart昭和54年 4 月19日） \\ (Code No. 34310)
}

\section{CORRECTION FACTOR OF RADIOISOTOPE CALIBRATOR FOR RADIOISOTOPE VOLUME AND THE VESSEL}

(Article received: Apr. 19, 1979)

\author{
By Kingo TANIGUCHI, \\ TADASHIGE MiYAKAWA and \\ IKKAKU DOINOBU \\ Department of Rodiology, Hiroshima Uni- \\ versity School Hospital \\ TADASHI SUNAYASHIKI \\ Research Institute for Nuclear Medicine \\ and Biology, Hiroshima University
}

\section{- Summary}

Radioisotope which is produced by milking system is first measured its activity and then prescribed for a patient. For this measurement, a radioisotope calibrator is used. At this time, correction of nuclide, activity, and location of the test material in the well is required.

We checked our two ionization chambers and a scintillation calibrator on the measurement error brought about by different radioisotope volume and container. For this purpose, we studied isodose curve, depth where real figure appears, and variation of the indicated value with time. As a result, we found out that there exists twice as much difference regarding the sensitivity depend on the depth in the well. And also, two apparatus of same type showed different isodose curve.

Enlargement of the volume of the test material also caused error. Isotope is usually contained in a syringe or vial when they are come into use. Here, sensitivity differes with the shapes of these containers as 
well as the quantity of the liquid in them. After this study, we can say that at Tc-99m, nearly $20 \%$ error is enevitable.

At this study, we made a chart to bring out a correction coefficient for each measuring apparatus to correct these errors caused by different volume and different containers.

This paper reports the necessity of these error corrections, accuracy, and everyday checking.

\section{1. 緒言}

近年の核医学検査においては，短半減期核種の使用が 急增しており，その多くはミルキングシステムを用いて 放射性同位元素を抽出している，乙の場合，抽出した放 射性同位元素の放射能量の測定を放射能量測定器（例え ばキュリーメータ，ドーズキャリブレータ）で行ない， その後, 患者に投与することが多い。これらの測定器は いずれも測定のために井戸型の空洞（以下ウエルと言う） に試料を入れて測定する形式である。

この測定に際しては，放射性同位元素の核種について 測定器の選択回路によって指示值の補正がなされており， その測定精度については，製作者の立場加らの検討1!， 使用者の相互比較 ${ }^{2} な と ゙ の$ 報告がみられるが，他に，放 射能量, 試料の置汃れる位置によって毛指示值汃異なる と考えられる(3) 種の電離箱型測定器 2 台 $(a, b)$ と他のシンチレーシ ョンタイプ1台（c）について，ウエル内の感度分布を 調べ，測定指示値の精度を検討し，補正係数を求めた。 同時に, 装置の安定指示に要する時間, 比放射能濃度依 存性等の検討もあわせ行なったので報告する。

\section{2. 装置及び材料}

使用装置: アロカ社筡キュリーメータで, IGC-1b 型, IGC-1 型（以下各々装置(a)，装置(b)という）の2台と感 度分布比較のため，IGC-2 型（以下装置(c)という)を使 用した。な挔装置(a)，(b)は検出器に電離箱をむちい，試 料を入れるウェルは直径 $7 \mathrm{~cm}$, 高さ $14 \mathrm{~cm}$ でする. 装 置(c)は検出器がプラスチックシンチレータでウエルは直 径 $7 \mathrm{~cm}$, 高さ $14.5 \mathrm{~cm}$ である.

注射器: 注射器内侧寸法 $3 \mathrm{ml}$ 用 $4.7 \mathrm{~cm} \times 0.9 \mathrm{~cm} \phi$, 同様 $5 \mathrm{~m} l$ 用 $3.8 \mathrm{~cm} \times 1.3 \mathrm{~cm} \phi, 10 \mathrm{~m} l$ 用 $6.0 \mathrm{~cm} \times 1.5$ $\mathrm{cm} \phi$ (注射器は規定の液量を満たした時の液面の高さで, 使用出来る最大容量はそれぞれ $3,6,12 \mathrm{ml}$ である.

バイアル: $30 \mathrm{ml}$ 用内側寸法 $2.7 \mathrm{~cm} \times 3.4 \mathrm{~cm}$ (バイ

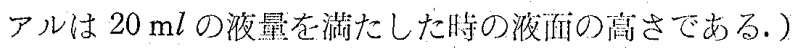
のものを用くた。

使朋放射性核種：Tc-99m, I-131 および Se-75 の3 核
糧.

\section{3. 実験方法および結果}

\section{1. 指示値の安定に要する時間}

当院に扣いて，キュリーメー夕が使用されるのは， Tc-99 m の測定が主であるととから, 模擬線源として, エネルギーが Tc-99 m 亿近く, 比較的半減期の長し点 を考慮して，Se-75 を用いた.アクリル製容器 $0.5 \mathrm{~cm} \times$ $0.5 \mathrm{~cm} \phi$ にe-75を密封し，ウエルの中心軸上で底面 がら $4 \mathrm{~cm}$ の高さに位置させて固定し, 装置に通霄後指 示值加努定するまでに要する時間的経過を調べた。なお 5 回の測定值の平均之標準偏差图に示した（Fig. 1).

装置(a), '(b)と屯に，装置の測定可能な状態になった直 後は指示値が高く, 時間が経過するに従い一定值に達す る. 装置の測定问能状態 (通電後約 1 分) の指示值につ いては，装置(a)で安定状態時の約1.4倍，装置(b)で約1.7 倍であった。両装置ともに指示值は装置の測定可能状態 後10分を経過すると安定し，指示值は一定になる。

\section{2. 比放射能濃度依存性}

$\mathrm{Tc}-99 \mathrm{~m}$ の $1 \mathrm{~m} l$ 溶液をマイクロピペットで倍数稀彩 を行ない, 备 $1 \mathrm{~m} l$ につて, キュリーメータの指示值 と放射能量の直線性を求めた. 結果をFig. 2 亿示すが, 比放射能婊度と指示值との間には，両装犆共に，ほぼ直 線性が琶められた。装置(b)梳拉よそ $100 \mu \mathrm{Ci}$ 以下で直線 性からわずかにはずれ，指示值が小さくなる傾问にある

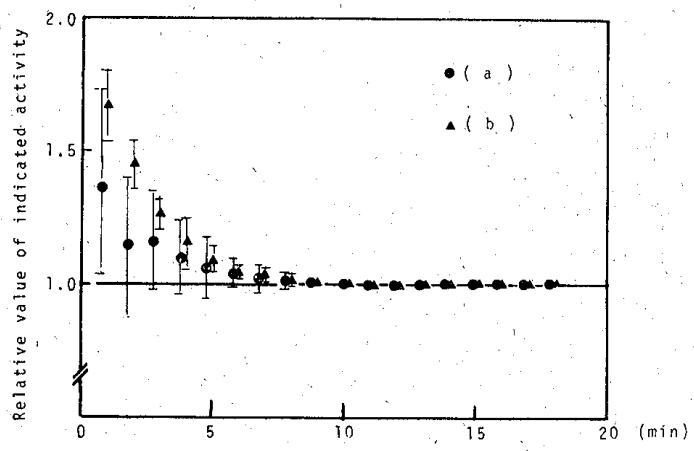

Time after power supplied with the calibrater.

Fig. 1 Relation between the time after swiching-on the calibrators and the indicated activity. 


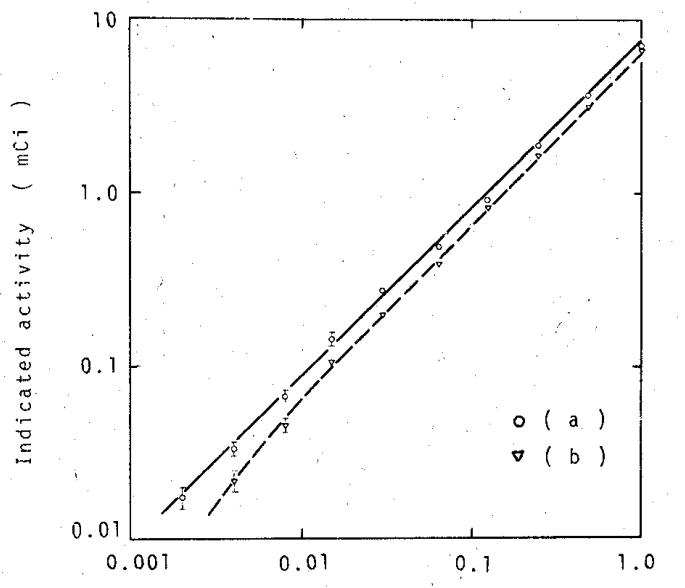

Rerative concentration of Tc-99m... (arbitrary)

Fig. 2 Linearity of the indicated activity for Tc- $99 \mathrm{~m}$.

が, 臨休上使用する範国内では問題にならない领域と考

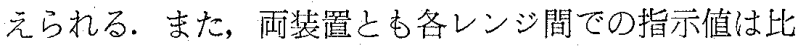
放射能濃度に対応して良好であった，放射能量が少なく なると統計的バラツキが大きくなるのは当然である.

\section{3. ウエル内感度分布}

ウエルの軸方向を $Z$ 軸として，ウエルの軸を直交する 二平面を仮定し，X面，Y面とした。乙の雨面内のいろ いろな位置で，感度分布を求めるために，ウエルの上部
から底部まで $1 \mathrm{~cm}$ 間隔で測定した。線源は, Tc-99 m を $5 \mathrm{~mm} \times 2 \mathrm{~mm} \phi$ の容器に密封して，それぞれの位置で 指示值を求め, ウエル内中心軸上最高感度部を 1.0 とし た (Fig. 3).

ウエル内の感度分布は Fig. 3 亿示すように装置(a), (b) 子屯に, ウェルの底部ほど感度が高く, 線源が上方に いくにつれて感度が低下した。 装置(c)では最高感度位置 がウエルの底部から $5 \mathrm{~cm}$ 上方にあり，線源位置が上下 そずれるに従い，Fig.4亿見られるような感度の低下が あった。な挹ウエルの上部は最高感度部の 0.5 以下の指 示值であった，また装置(a)，(b)，(c)とも，ウエルの側壁 亿近づくほど感度は上㫒し，3台の装置ともにX，Y雨 面の闇に，わずかな感度分布の相違が見られるが，特別 にある方向に偏っているととはないままた，X，Y耐断 面で中心粙上の感度は一致するはずであるが，使用した 線源は長さ $5 \mathrm{~mm}$ であり，壁方向に用いたことによる測 定望差と考元られる。

\section{4. 真の値を指示する深さ}

Tc-99m では検定した武料が得られないので, 既知放 射能量（a 装置では $85 \mu \mathrm{Ci} ， b$ 装埴では $98 \mu \mathrm{Ci}$ ) の線源, I-131 カプセルを用い，ウエルの中心軸上において深さ を桨え，その指示値加，真の值を示すウエル内の位置

(a) IGC-1b

(b) $I G C-1$

(c) IGC-?
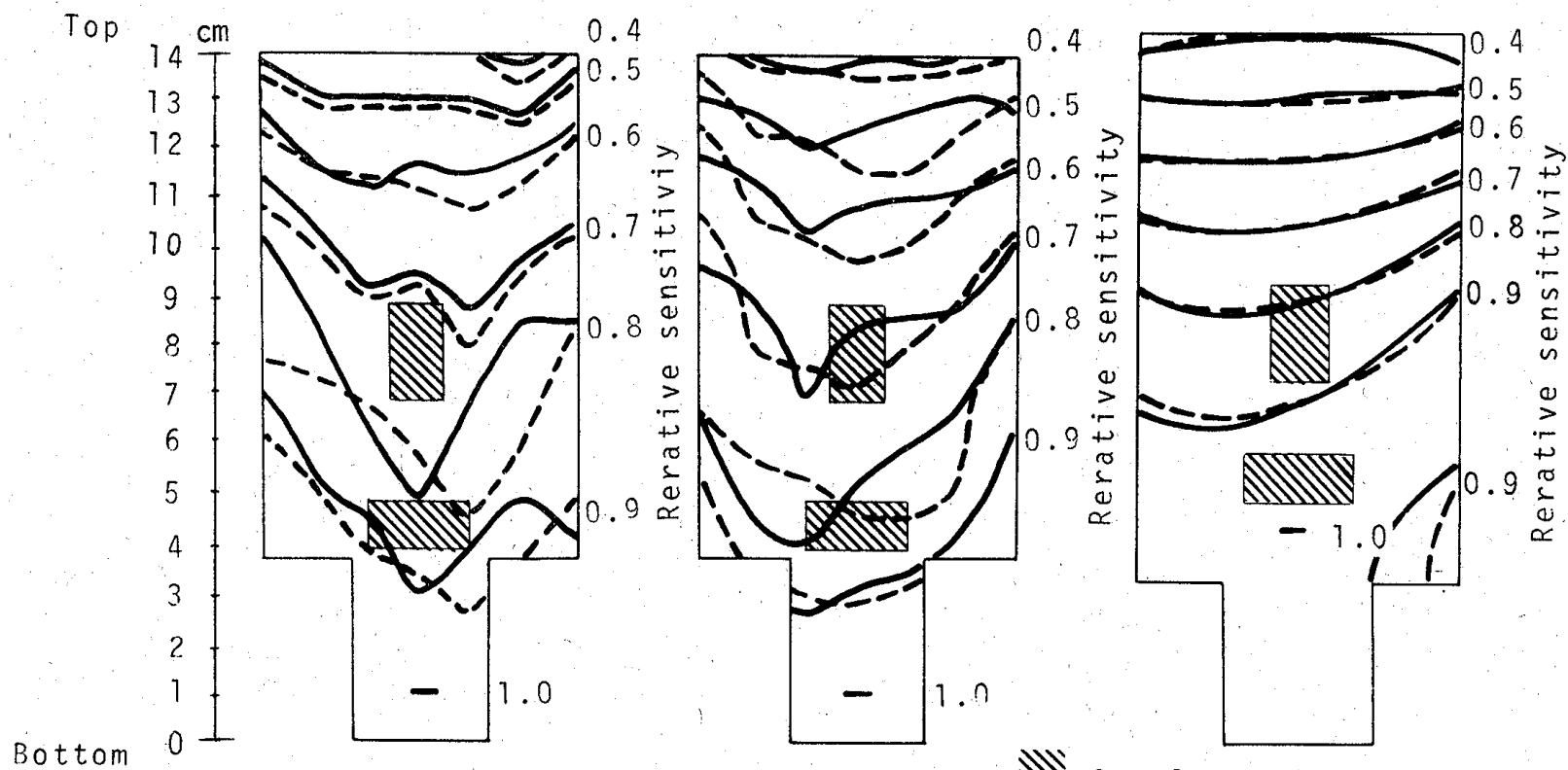

Sample position

-... Iscdose curve in $x$ vertical plane

- Isodose curve in $Y$ vertical plane

Fig. 3 Sensitivity distribution of well chamber calibrators to Tc-99m. 


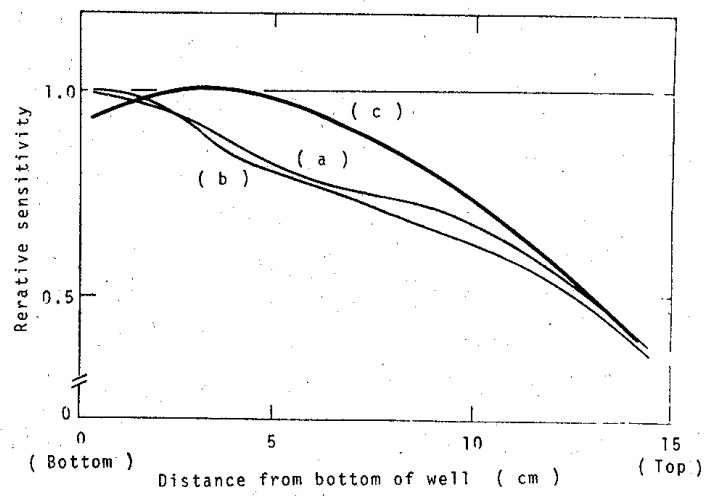

Fig. 4 Relative response of well chamber calibrators to Tc-99m sample, normalized to the maximum readings. (a), (b) and (c) represent IGC1b, IGC-1 and IGC-2 calibrators respectively.

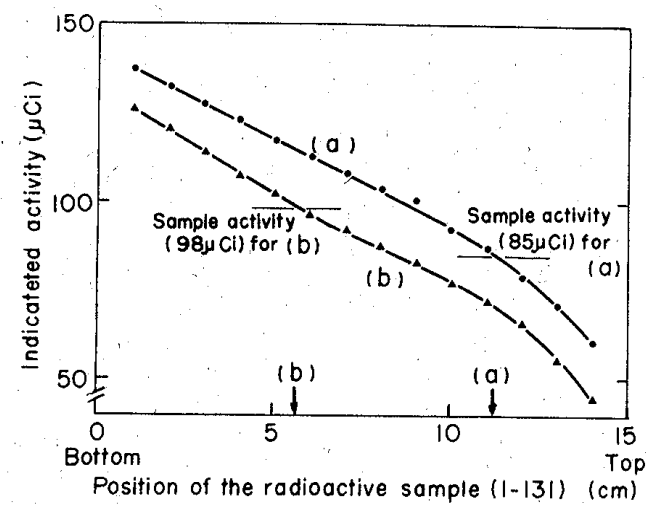

Fig. 5 Relation between the position of I131 sample and sensitivity of central axis for ionization well chamber.

を求めた（Fig. 5)，すなわち(a)装置では底部より 11.2 $\mathrm{cm}$ ，(b)装置では $5.6 \mathrm{~cm}$ の位置で放射能量之指示値が一 致した。

次にこの結果を Tc-99 $\mathrm{m}$ 亿適用するため, 上記で求 めた感度分有と Tc-99 $\mathrm{m}$ の感度分布を比較したところ, ほぼ同一の傾向を示した．そこて Tc-99 m の感度分布 を，上記で得た位置を基準とした感度分布に換算し，

Fig. 6 亿示した. とれは試料がおかれた位置での指示值 と真值との比を示すものである.

\section{5 指示値の経時変化}

両装置に通電後10分間以上ウォー之ングアップした安 定状態で， 3 力月間 1 週おきに指示值の変動をしらべた (Fig. 7).

この時の線源は Se-75 を用い，測定位置はウェルの底 部より $4 \mathrm{~cm}$ 上方で, 物理的減琶渗の補正老行ない図示 した．指示值は装韁(a)で $85.8 \pm 2.1 \mu \mathrm{Ci}$ ，装罣(b)で 66.4 $\pm 3.0 \mu \mathrm{Ci}$ であった。

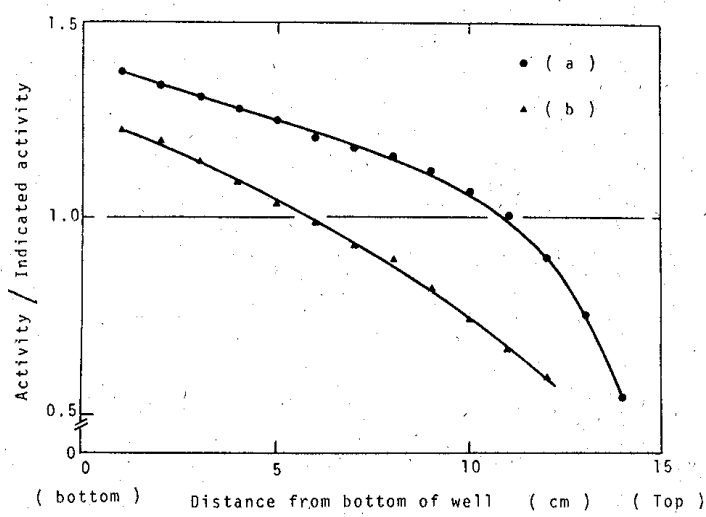

Fig, 6 Relation between the position of Tc-99m sample and sensitivity ratio of central axis for ionization well chambers.

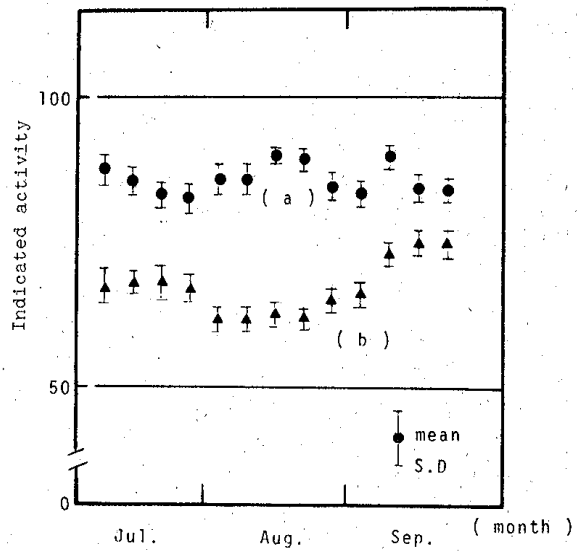

Fig. 7 Variation of indicated activity of calibrators for three months.

\section{6 バィアル, 注射器での感度}

前項までの事験は，小線源（点線源）を用したもので あるが，日常使用される特は，容器，液量ともにそれと は異なる．乙のような時の指示値の変化について，バイ アルおよび注射器それぞれに專用の保持具を用い，注射 器の種類や液量を変えて検討した. Fig. 8 は Tc-99m の 放射能量を一定にして，順次水を加え液量を増加させ指 示値の変化を調べたあのである.

これから明らかなように，注射器で差が大きく，最大 20\%に達した。バイアルでは $5 \%$ 程度であった。これは 液量による高さの変化での影響が大きく，補正を考慮す る場合が生ずると考えられる。

\section{7 補 正 係 数}

上記垁験で，試料の測定位置と注射器の種類，バイア ルの液䁷によって，指ボ值の補正加必亚であるととがわ からたので，われわれは(a)，(b) 2 台の装睢について，夷 駼 3.4，3.6 汃ら補正係数を求め Fig. 9 亿示した。 

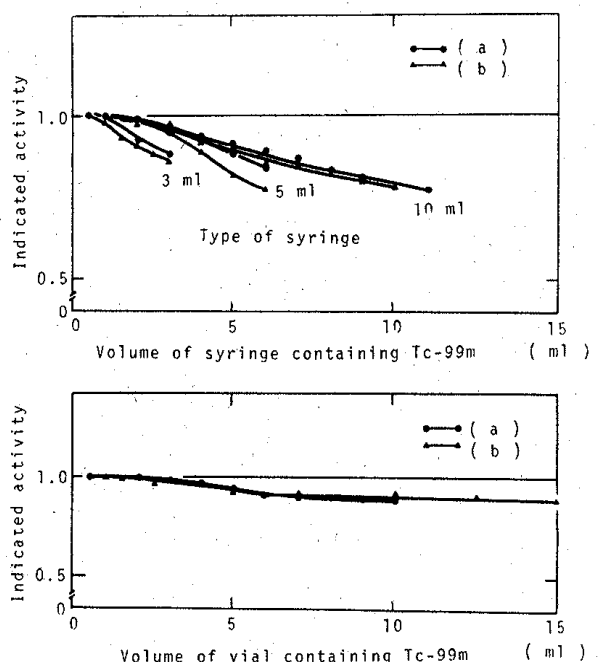

Fig. 8 Variation of sensitivity with volume of syringe and vial containing Tc-99m.

(a) and (b) represent IGC-

$1 \mathrm{~b}$ and IGC-1 calibrators respectively.
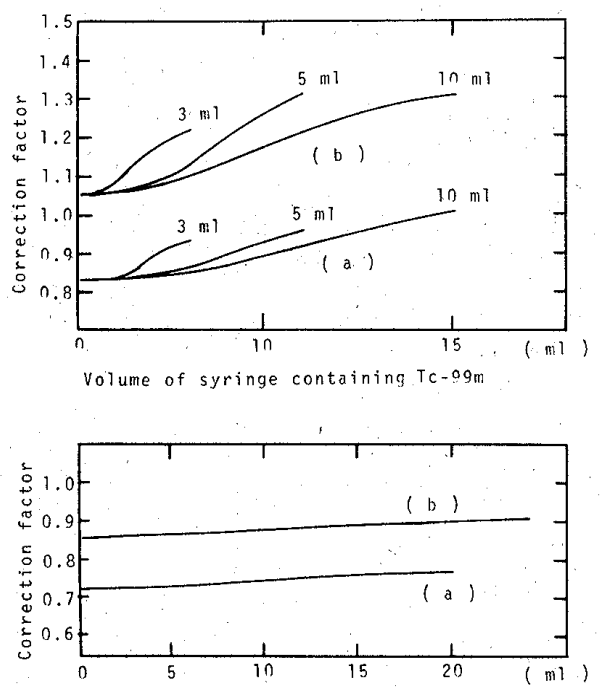

Volume of vial containing Tc-99m

Fig. 9 Relation between correction factors with volume of syringe and vial cotaining Tc- $99 \mathrm{~m}$.

日常キュリーメータを使用する場合は，武料の液量が わかっているので，メータの指示値に Fig. 9 から求め た補正係数を乗ずることで真の放射能量を求めることが 出来る.

\section{4. 考察}

購入してから数年を経ている電雕箱式の同-...機種 2 占 执よびシンチレーションタイプ1台の装䈯について，ウ

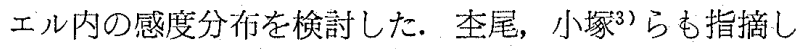

ているように, 注射器, バイアルの大きさ, 液面の高さ, 湘定位置による幾何学的效率などにより, 最大 $20 \%$ 程度 の誤差が生ずることが楒められれた。この原因はウェル内 の感度分布が異なるためと考えられる。また，ウ土ルの 形状が四筒であるため，感度分布の検討結果からもわか るように試料の直径による影響は比較的少なく，液面の 高さによる影響が大きく，その補正が重要であるととが 明膫である. また，同一メ一カーの電離箱式同一機種で あウエル内の感度分布の状態が相違し, 真の值を示す試 料位犆が異なった。 2 台の装置の指示値の差は注射器で 20\%，バイアルで15\%であった. とのことは各装置によ って，それぞれ校正の必要性を示唆している.

ウエル内感度分布の位置依存性について松平ら ${ }^{45)}$ は, Tc-99 m で20\%，I-131 で4\%であったと報告している が，これは本笑験結果より少なく，各々の装品によるウ エル内の感度分有の相違によるものと考えられる．また， 検出器にウエル形シンチレータを使用したディジタルキ ュリーメータ (IGC-2 型) についても同様な実験を行な つたが，武料室内の感度分有は電離箱式に比較して改善 されている (Fig. 4).

次に装置の安定性については，装置(a)で士 $2.5 \%$ ，装 置(b)で士 $4.5 \%$ 変動があり 3 力月間に一定の傾向は見 られず，またとの程度の変動は臨床利用に問題はなりと 考えられる.

キュリーメータを使用し，思者に投与する真の放射能 量を知るためには，核種選択回路の補正が正しく校正さ れていること浪は重要であるが，それに加えて，試料の 測定位置と注射器, バイアルの液量について，名装置で の補正が必要であるととがわかった．备々の装置，乙と では(a), (b) 2 台の装置について補正係数を求め, 図示し た (Fig. 9).

キュリーメータは液体，固体武洣の放射能量を簡単に 測定出来る点では，利用佂值の高い装置であるが，試料 を測定する際に，検討したような誤差の要因を含んでい る. 放射性同位元素の管理上，㭧者に投与する量を正碓 に知る事が重要であるととから，個々の装置についての 校正と定期的なチェック，補正が必要であると言える.

\section{5. 結 論}

電離箱式同一機種 2 台について，(1)指示值の安定に要 する時間，(2)比放射能濃度依存性，(3)ウエル内感度分布， (4)真の值を指示す歹深さ，(5)指示值の経時変化，(6)バイ アル，注射器での箵度，等について検討した結果，注射 器, バイアルの液量による液面の高さの変化による影響 
が大きく, 注射器で最大 $20 \%$, バイアルで $5 \%$ の䛊差が, また，2台の装置間での指示值の差は，注射器で $20 \%$ ， バイアルで15\%であった. そのため，補正が必要である ととがわかったので，われわれは(a)，(b) 2 台の装置につ いて補正係数を求如，Fig. 9 亿示した。

日常キュリーメータを使肘する場全は, 倵料の液量が わかっているので, メー夕の指示值に Fig. 9 から求め た補正係数を乗ずるととで喜の放射能量を求めることが 出来る。

䛊差の主な原因感度分布の不均一によるものであり， 電離箱の電位分布の改善が重要になるが，乙れは霆離箱 容積を大きくすることで改善されよう。また，測定器の 設置場所の線量率が試料の測定值に付加されるととで測 定器の遮嫩などあ将慮されるうとしている。乙れらを拿

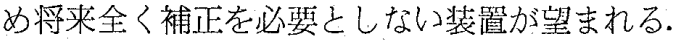

本丰験の機会を与えていただいた広島大学医学部附属 病院放射線部佐々木正博满陪，ならびに加藤良隆助手に 深く感謝します。またご校閲いただした広島大学原爆放 射能医学研究所竹下健児教授に心から扔礼申し上げます。 本論文の一部は第32回日本放射線技術学会総会 (1976,
5 ，福島）及び第17回日本放射線技術学会中四国部会 (1976，10，松山）で発表した。

\section{文献}

1) Suzuki, K., Suzuki, M. N. and Weis, A. M. : Analysis of a Radioisotope Calibrator. J. Nucl. Technol. 4, 193-198, (1977).

2) Hare, D. L., Hendee, W. R., Whitney, W. P. and Chaney, E, L.: Accuracy of Well Ionization Chamber Isotope Calibrators. J. Nucl. Med. 15, 1138-1141, (1974).

3) 圭尾 炤, 小塚㢣信：固体，液体用電離箱による RI 試料の放射能測定， Radioisotope. 12，419-422, (1963)

4) 松平正道, 山田正人, 久甘欤一：ラジオアイソトー プドーズキャリブレータの性能の基憷的検討とその 問題点について，核医学，15，164，(1978).

5）松平正道，松本，進，计井秀夫，山田正人：ドーズ キャリブレータの感度校正法の検討，日放技学誌， 33, 647, (1977).

社団法人 日本放射線技術学会替助会員

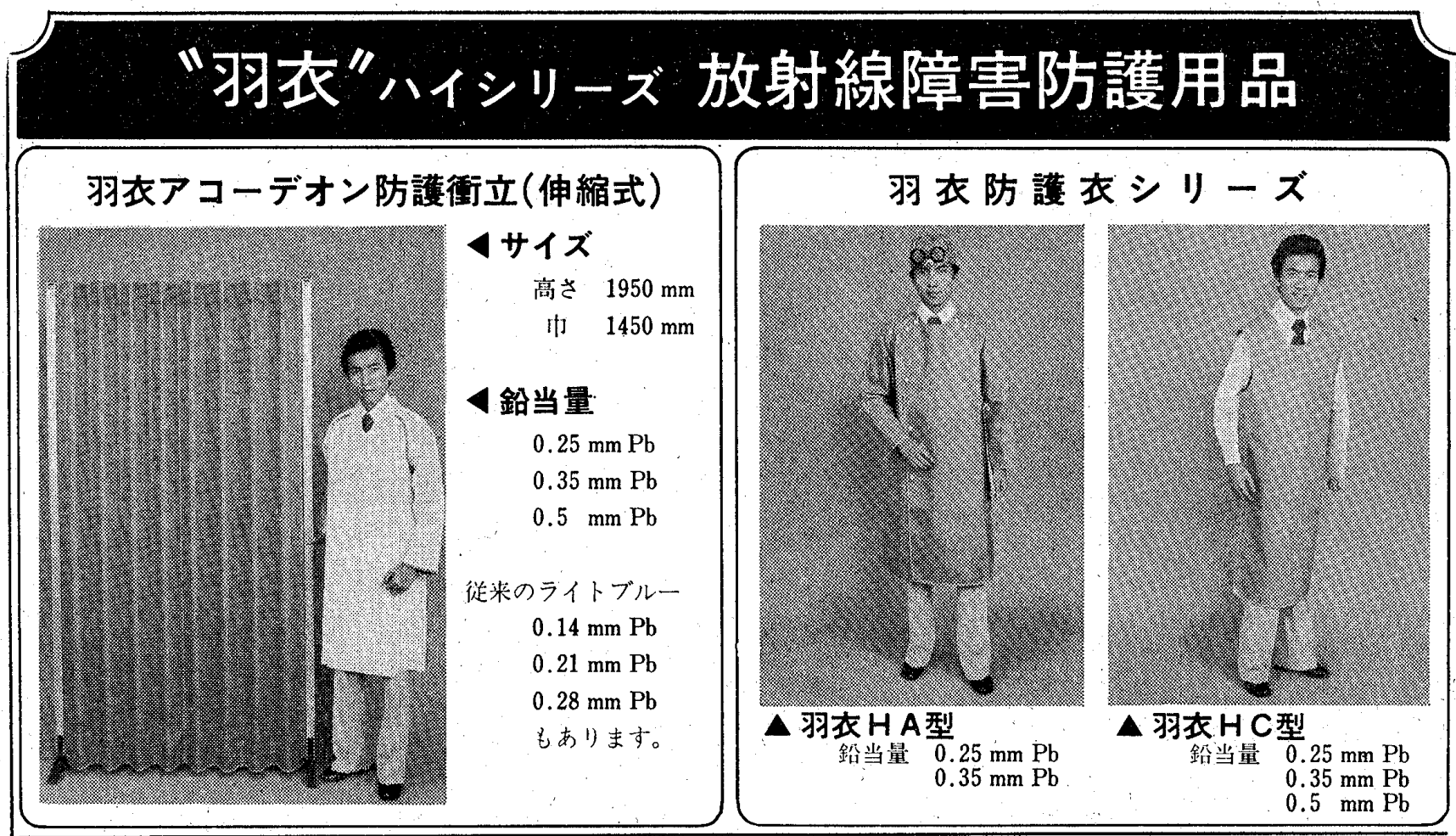

放射線障害予防衣のパイオニア

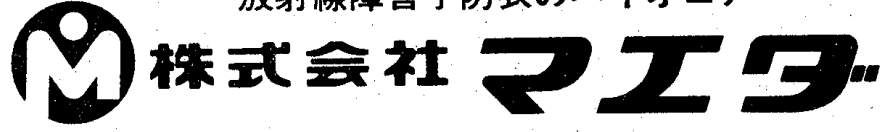

巴113 東京都文京区本郷3-11-10 電話 $03(811) 7315$ (代表) 